\title{
Aktivitas Antibakteri Ekstrak Metanol Rumput Laut Gracilaria verrucosa, Greville, 1830 (Florideophyceae : Gracilariaceae) di Balai Besar Perikanan Budidaya Air Payau Jepara
}

\author{
Radhian Wikanarto Widodo*, Subagiyo, Rini Pramesti \\ Departemen IImu Kelautan, Fakultas Perikanan dan IImu Kelautan, Universitas Diponegoro \\ JI. Prof. H. Soedarto S.H, Tembalang,Semarang, Jawa Tengah 50275 Indonesia \\ ${ }^{*}$ Corresponding author, e-mail:radhian.wika@gmail.com
}

\begin{abstract}
ABSTRAK : Infeksi bakteri patogen menjadi masalah kesehatan dunia. Antibiotik untuk penanggulangan infeksi menjadikan bakteri resisten karena pemakaiannya tidak sesuai dosis. Permasalahan ini dapat diatasi salah satunya dengan pencarian sumber antibiotik baru termasuk diantaranya pada rumput laut. Penelitian ini bertujuan untuk menentukan aktivitas antibakteri ekstrak metanol G. verrucosa terhadap Escherichia coli, Bacillus cereus, Staphylococcus epidermidis, Pseudomonas aeruginosa, Vibrio anguillarum, dan Vibrio alginolyticus. Penelitian dilakukan dengan metode eksperimental laboratoris. Sampel rumput laut hasil budidaya Balai Besar Perikanan Budidaya Air Payau (BBPBAP) Jepara dikeringkan kemudian dimaserasi dengan metanol selama 2x24 jam. Aktivitas antibakteri ekstrak diuji pada konsentrasi $100 \mu \mathrm{g} / \mathrm{disk}, 50 \mu \mathrm{g} / \mathrm{disk}, 25 \mu \mathrm{g} / \mathrm{disk}$, dan $10 \mu \mathrm{g} /$ disk kemudian dilakukan uji fitokimia. Hasil uji aktivitas antibakteri menunjukkan bahwa ekstrak metanol G. verrucosa tidak memiliki aktivitas antibakteri. Uji fitokimia menunjukkan ekstrak mengandung flavonoid, saponin, steroid, dan triterpenoid.
\end{abstract}

Kata kunci: Gracilaria verrucosa, Antibakteri, Metanol

Antibacterial Activity of Gracilaria verrucosa Seaweed Methanol Extract, Greville, 1830 (Florideophyceae: Gracilariaceae) at the Brackish Aquaculture Fisheries Center Jepara

ABSTRACT : Pathogenic bacterial infection become a world health problem. Antibiotics for prevention of infection make bacteria resistant due to the incorrect dosage. One of these problems can be overcome by finding a new source of antibiotics including seaweed. This study aims to determine the antibacterial activity of methanol extract of $G$. verrucosa against Escherichia coli, Bacillus cereus, Staphylococcus epidermidis, Pseudomonas aeruginosa, Vibrio anguillarum, and Vibrio alginolyticus. Laboratory experimental method was used in this study. Seaweed samples from the cultivation at Brackish Water Aquaculture Center (BBPBAP) Jepara were dried and then macerated with methanol for $2 \times 24$ hours. The antibacterial activity of the extract was tested at concentration of $100 \mu \mathrm{g} /$ disk, $50 \mu \mathrm{g} /$ disk, $25 \mu \mathrm{g} /$ disk, and $10 \mu \mathrm{g} /$ disk then phytochemical tests were carried out. The results of antibacterial activity test showed that $G$. verrucosa methanol extract did not have antibacterial activity. The phytochemical test showed that seaweed extract contained flavonoids, saponins, steroids, and triterpenoids

Keywords: Gracilaria verrucosa, Antibacterial, Methanol

\section{PENDAHULUAN}

Penyakit infeksi menjadi salah satu permasalahan kesehatan dan akuakultur dunia. Sumber utama dari penyakit pada manusia dan organisme akuakultur diantaranya adalah bakteri patogen (Sudheesh et al., 2012; Hessling et al., 2017). Selama ini antibiotik biasa digunakan dalam penanggulangan infeksi bakteri, namun penggunaan dengan dosis yang tidak sesuai menyebabkan bakteri menjadi resisten (Ventola, 2015). Perlu dilakukan upaya pencarian antibiotik baru.

Organisme laut seperti rumput laut dikenal sebagai sumber berbagai senyawa aktif, oleh karena itu banyak dimanfaatkan sebagai bahan pangan, kosmetik, dan farmasi (Riyanto et al., 2013; Anis et al., 2017). Hal ini karena senyawa bioaktifnya memiliki aktivitas antibakteri, 
antioksidan, antivirus, antikanker, antikoagulan, dan antiinflamasi (Perez et al., 2016). Senyawa bioaktif merupakan hasil metabolit sekunder yang disintesis saat tumbuhan mengalami stres lingkungan. Rumput laut Gracilaria verrucosa mengandung senyawa alkaloid, flavonoid, tannin, steroid, dan fenol yang mampu menghambat pertumbuhan bakteri (Maftuch et al., 2016). Senyawa ini diperoleh dengan ekstraksi menggunakan pelarut polar. Metanol menghasilkan rendemen ekstrak rumput laut yang lebih tinggi diantara pelarut polar (Rusli et al., 2016).

Hasil penelitian Widowati et al. (2014) dan Maftuch et al. (2016) menunjukkan G. verrucosa hasil budidaya berpotensi sebagai antibakteri. Hal ini membawa kepada pemikiran apakah semua G. verrucosa hasil budidaya memiliki aktivitas antibakteri. Maka dalam penelitian ini dilakukan pengujian ekstrak metanol G. verrucosa hasil budidaya Balai Besar Perikanan Budidaya Air Payau $(B B P B A P)$ Jepara.

\section{MATERI DAN METODE}

Materi penelitian adalah rumput laut $G$. verrucosa hasil budidaya tambak BBPBAP Jepara yang berumur \pm 30 hari. Bakteri uji $B$. cereus, $E$. coli, $P$. aeruginosa, $S$. epidermidis, $V$. alginolyticus, dan V. anguillarum diperoleh dari Laboratorium Tropical Marine Biotechnology, Fakultas Perikanan dan IImu Kelautan, Universitas Diponegoro, Semarang. Metode yang digunakan pada penelitian ini adalah eksperimental laboratoris. Metode ini bertujuan menyelidiki sebab akibat suatu kejadian dengan menguji kelompok eksperimental terhadap kondisi perlakuan dan membandingkannya dengan kontrol (Suryabrata, 2003).

Rumput laut dicuci dengan air mengalir untuk menghilangkan garam dan kotoran yang menempel kemudian dikering anginkan selama \pm 5 hari, rumput laut kering dipotong kecil-kecil. Proses ekstraksi menggunakan teknik maserasi dengan perbandingan pelarut metanol dan sampel sebesar 4:1 selama $2 \times 24$ jam. Hasil maserasi dipekatkan menggunakan rotary evaporator pada suhu $38{ }^{\circ} \mathrm{C}$ kemudian dikeringkan dengan nitrogen cair. Rendemen ekstrak dihitung dengan rumus (Wijaya et al., 2018): Rendemen (\%) $=\frac{A-B}{C} \times 100 \%$. Keterangan : $\mathrm{A}=$ Berat vial + ekstrak; $\mathrm{B}=$ Berat vial kosong; $\mathrm{C}=$ Berat sampel yang diekstraksi

Suspensi bakteri dibuat dengan mengambil satu koloni bakteri uji dengan ose dan dipindahkan ke media cair pada tabung reaksi. Suspensi lalu dihomogenkan menggunakan vortex mixer. Kepadatan sel ditetapkan dengan cara dibandingkan dengan reagen McFarland 0,5 yang setara dengan $\pm 10^{8}$ sel bakteri (Kusuma et al., 2015). Uji fitokimia dilakukan untuk mengetahui kandungan senyawa bioaktif rumput laut. Ekstrak diuji kandungan senyawa flavonoid, alkaloid, saponin, tanin, steroid, dan triterpenoid.

Uji aktivitas antibakteri dilakukan menggunakan metode difusi paper disc. Larutan stok ekstrak uji konsentrasi $200 \mu \mathrm{g} /$ disk dibuat dengan mencampurkan ekstrak dengan DMSO yang bersifat polar (Costa et al., 2017). Larutan stok kemudian diencerkan menjadi konsentrasi uji 10 $\mu \mathrm{g} / \mathrm{disk}, 25 \mu \mathrm{g} / \mathrm{disk}, 50 \mu \mathrm{g} / \mathrm{disk}$, dan $100 \mu \mathrm{g} /$ disk (Modifikasi Widowati et al., 2014).

Suspensi bakteri diambil sebanyak $80 \mu \mathrm{L}$ lalu dituangkan ke atas media padat Nutrient Agar kemudian diratakan dengan spreader. Larutan ekstrak uji diambil sebanyak $10 \mu \mathrm{L}$ kemudian diteteskan pada paper disc. Paper disc diletakan di permukaan agar secara aseptis dan diinkubasi pada suhu $37^{\circ} \mathrm{C}$ selama $2 \times 24$ jam. Diameter zona hambat diukur setiap 24 jam dengan rumus (Kaharap et al., 2016) :

Diameter $=\frac{(D v-D p)+(D h-D p)}{2}$

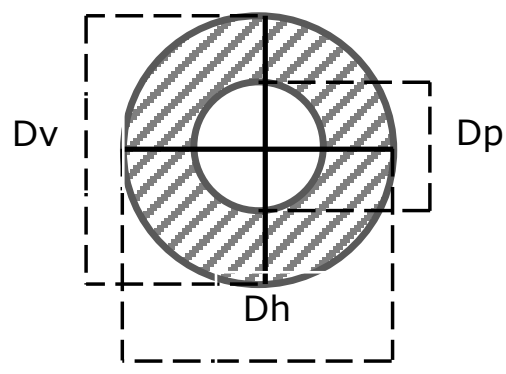

Keterangan $: \mathrm{Dv}=$ Diameter vertikal; $\mathrm{Dh}=$ Diameter horizontal; $\mathrm{Dp}=$ Diameter paper disc 


\section{HASIL DAN PEMBAHASAN}

Hasil ekstraksi metanol diperoleh dalam bentuk pasta berwarna hijau dengan rendemen $1,635 \%$ berat kering rumput laut. Warna hijau diduga berasal dari pigmen klorofil a. Menurut Ak \& Yucesan (2012), G. verrucosa mengandung pigmen klorofil a, karotenoid, fikoeritrin, serta fikosianin. Pigmen ini menyerap cahaya biru dan merah sehingga memantulkan warna hijau.

Hasil uji Fitokimia (Tabel 1) menunjukkan ekstrak metanol G. verrucosa mengandung senyawa flavonoid, saponin, steroid, dan triterpenoid. Senyawa-senyawa ini umumnya disintesis pada fase transisi pertumbuhan aktif menuju stasioner. Rumput laut dengan umur \pm 30 hari dianggap mampu mensintesis senyawa bioaktif. Masyahoro \& Mappiratu (2010), rumput laut mengalami fase pertumbuhan aktif pada umur 1-3 minggu dan fase stasioner pada minggu ke 4. Penelitian terdahulu menunjukkan senyawa flavonoid, saponin, steroid, dan triterpenoid tidak memiliki aktivitas antibakteri (Arabski et al., 2012; Mokoka et al., 2013; Wafa et al., 2016; Dogan et al., 2017). Kandungan senyawa serupa dapat memberikan aktivitas bioaktif berbeda. Diachanty et al. (2017), rumput laut dengan kandungan flavonoid, saponin, steroid, dan triterpenoid memiliki aktivitas antioksidan tinggi. Kolam budidaya yang dangkal diduga menyebabkan tingginya paparan cahaya terhadap rumput laut. Karimil et al. (2013), peningkatan intensitas cahaya berbanding lurus dengan aktivitas antioksidan.

Uji aktivitas antibakteri (Tabel 2) menunjukkan kloramfenikol dapat menghambat pertumbuhan bakteri uji. Menurut Kohanski et al. (2010), kloramfenikol menghambat pertumbuhan bakteri melalui mekanisme pencegahan sintesis protein. Kloramfenikol merupakan antibiotik spektrum luas sehingga dapat digunakan terhadap bakteri Gram positif dan negatif (Shukla et al., 2011). Zona hambat terbesar yang dihasilkan oleh kloramfenikol terjadi pada bakteri $V$. anguillarum dan $V$. alginolyticus yaitu $28,9 \mathrm{~mm}$ serta $27 \mathrm{~mm}$. Hal ini menunjukkan kloramfenikol efektif dalam menghambat bakteri Vibrio. Kitiyodom et al. (2010) menyatakan bakteri Vibrio rentan terhadap kloramfenikol. Penurunan zona hambat terjadi pada semua bakteri uji setelah 24 jam, kecuali $V$. alginolyticus. Morita et al. (2014), kloramfenikol bersifat bakteriostatik terhadap sebagian besar bakteri dan bakteriosidal pada beberapa spesies. Zona hambat terhadap $P$. aeruginosa mengalami penurunan terbesar, yakni 10,6 mm. Hal ini dimungkinkan kloramfenikol sulit menekan pertumbuhan $P$. aeruginosa karena kemampuannya menghasilkan biofilm (Borriello et al., 2004).

Hasil uji ekstrak metanol G. verrucosa (Tabel 2) tidak menunjukkan aktivitas antibakteri. Hasil yang sama (Oumaskour et al., 2013), ekstrak metanol G. verrucosa pada konsentrasi 500 $\mu \mathrm{g} / \mathrm{disk}$ tidak menghambat $B$. cereus. Hal ini diduga mekanisme pertahanan bakteri. $B$. cereus mampu membentuk spora dan mensintesis $\beta$-Lactamase sehingga meningkatkan resistensinya terhadap antibiotik (Louie et al., 2011; Owusu-Kwarteng et al., 2017). Widowati et al. (2014), ekstrak yang sama pada konsentrasi $65 \mu \mathrm{g} /$ disk tidak menunjukkan zona hambat terhadap $\mathrm{V}$. alginolyticus. Penelitian lain (Bansemir et al., 2006), ekstrak metanol pada konsentrasi 2000 $\mu \mathrm{g} /$ disk tidak menunjukkan zona hambat terhadap $V$. anguillarum. Bakteri Vibrio diduga membentuk biofilm sehingga zona hambat tidak tampak. Vibrio alginolyticus dan $V$. anguillarum mampu membentuk biofilm sebagai perlindungan terhadap senyawa antibakteri (You et al., 2007; Ruwandeepika et al., 2012). Hasil ini juga berbeda dengan penelitian yang ada. Penelitian Mohanta \& Padhi (2016) dengan ekstrak metanol G. verrucosa membentuk zona hambat sebesar $18 \mathrm{~mm}$ pada $E$. coli dan $16,3 \mathrm{~mm}$ pada $P$. aeruginosa dengan konsentrasi $1000 \mu \mathrm{g} /$ disk. Siregar et

Tabel 1. Hasil Uji Fitokimia Ekstrak G. Verrucosa

\begin{tabular}{ccc}
\hline No & Parameter Uji & Hasil \\
\hline 1. & Flavonoid & + (Positif) \\
2. & Alkaloid & - (Negatif) \\
3. & Saponin & + (Positif) \\
4. & Tanin & - (Negatif) \\
5. & Steroid & + (Positif) \\
6. & Triterpenoid & + (Positif) \\
\hline
\end{tabular}


Tabel 2. Aktivitas Antibakteri Ekstrak Metanol G. verrucosa (Diameter Zona Hambat (mm))

\begin{tabular}{|c|c|c|c|c|c|c|c|}
\hline \multirow{2}{*}{\multicolumn{2}{|c|}{ Bakteri Uji }} & \multicolumn{6}{|c|}{ Konsentrasi Uji ( $\mu \mathrm{g} /$ disk) } \\
\hline & & \multirow{2}{*}{$\frac{10}{-}$} & \multirow{2}{*}{$\frac{25}{-}$} & \multirow{2}{*}{$\frac{50}{-}$} & \multirow{2}{*}{$\frac{100}{-}$} & \multirow{2}{*}{$\frac{\text { Kontrol }+ \text { ) }}{24,5}$} & \multirow{2}{*}{$\frac{\text { Kontrol (-) }}{-}$} \\
\hline & 24 jam & & & & & & \\
\hline B. cereus & 48 jam & - & - & - & - & 24 & - \\
\hline \multirow{2}{*}{ E. coli } & 24 jam & - & - & - & - & 22,5 & - \\
\hline & 48 jam & - & - & - & - & 20,5 & - \\
\hline \multirow{2}{*}{$P$. aeruginosa } & 24 jam & - & - & - & - & 23,8 & - \\
\hline & 48 jam & - & - & - & - & 13,2 & - \\
\hline \multirow{2}{*}{ S. epidermidis } & 24 jam & - & - & - & - & 21,5 & - \\
\hline & 48 jam & - & - & - & - & 11,8 & - \\
\hline \multirow{2}{*}{ V. alginolyticus } & 24 jam & - & - & - & - & 26,9 & - \\
\hline & 48 jam & - & - & - & - & 27 & - \\
\hline \multirow{2}{*}{ V. anguillarum } & 24 jam & - & - & - & - & 28,9 & - \\
\hline & 48 jam & - & - & - & - & 26,6 & - \\
\hline
\end{tabular}

al. (2012), ekstrak yang sama dengan konsentrasi $200 \mu \mathrm{g} /$ disk membentuk zona hambat sebesar $5 \mathrm{~mm}$ terhadap $S$. epidermidis. Hasil yang berbeda pada penelitian ini dapat disebabkan oleh konsentrasi uji yang rendah. Chandrasekaran et al. (2014), MIC ekstrak metanol G. verrucosa adalah $5 \mu \mathrm{g} /$ disk. MIC merupakan nilai konsentrasi minimum yang menunjukkan penghambatan terhadap bakteri. Konsentrasi uji yang melebihi nilai MIC dianggap cukup untuk menunjukkan adanya aktivitas antibakteri.

Faktor biotik seperti predasi dan kompetisi spasial berpengaruh pada jenis senyawa bioaktif yang disintesis (Marti et al., 2004). Senyawa ini berfungsi sebagai pertahanan terhadap organisme lain. Jenis organisme tambak yang ditemukan bukan predator atau kompetitor sehingga diduga tidak terjadi predasi dan kompetisi spasial. Hal ini sesuai Maftuch et al. (2016), G. verrucosa hasil budidaya kolam polikultur dengan udang, bandeng, dan spesies rumput laut lain memiliki aktivitas antibakteri. Edwards \& Connell (2012), kompetisi spasial dapat terjadi karena keterbatasan sumber nutrisi. Nutrisi tambak dianggap terpenuhi dengan adanya pemberian pupuk organik.

Teknik budidaya broadcast menyebabkan rumput laut berkembang secara vegetatif tanpa ada variasi genetik. Hal ini diduga mempengaruhi kemampuannya dalam mensintesis senyawa bioaktif. Largo et al. (1995), propagasi vegetatif rumput laut budidaya menurunkan sistem kekebalan terhadap infeksi bakteri patogen. Variasi gen yang terbatas dapat meningkatkan kerentanannya terhadap penyakit (Loureiro et al., 2015). Ketahanannya terhadap infeksi bakteri patogen dipengaruhi oleh kemampuan dalam mensintesis senyawa antibakteri.

\section{KESIMPULAN}

Ekstrak metanol G. verrucosa tidak memiliki aktivitas antibakteri terhadap B. cereus, E. coli, $P$. aeruginosa, $S$. epidermidis, $V$. alginolyticus, dan $V$. anguillarum. Ekstrak ini mengandung senyawa bioaktif berupa flavonoid, saponin, steroid, dan triterpenoid.

\section{DAFTAR PUSTAKA}

Ak, I. \& Yücesan, M. 2012. Effect of Light Intensity on the Pigment Composition of Gracilaria verrucosa (Rhodophyta). Fresenius Environmental Bulletin, 21(8):2126-2131.

Anis, M., Ahmed, S. \& Hasan, M.M. 2017. Algae as Nutrition, Medicine and Cosmetic: The Forgotten History, Present Status and Future Trends. World Journal of Pharmacy and Pharmaceutical Sciences, 6(6):1934-1959.

Arabski, M., Węgierek-Ciuk, A., Czerwonka, G., Lankoff, A. \& Kaca, W. 2012. Effects of Saponins against Clinical E. coli Strains and Eukaryotic Cell Line. Journal of Biomedicine and Biotechnology, 12(4):234-242. 
Bansemir, A., Blume, M., Schröder, S. \& Lindequist, U.,. 2006. Screening of Cultivated Seaweeds for Antibacterial Activity against Fish Pathogenic Bacteria. Aquaculture, 252(1):79-84.

Borriello, G., Werner, E., Roe, F., Kim, A.M., Ehrlich, G.D. \& Stewart, P.S. 2004. Oxygen Limitation Contributes to Antibiotic Tolerance of Pseudomonas aeruginosa in Biofilms. Antimicrobial Agents and Chemotherapy, 48(7):2659-2664.

Chandrasekaran, M., Venkatesalu, V. \& Raj, G.A., 2014. Antibacterial Activity of Selected Marine Macro Algae against Vancomycin Resistant Enterococcus faecalis. Journal of Coastal Life Medicine, 2(12):940-946.

Costa, L. de A., Henrique Fernandes Ottoni, M., dos Santos, M., Meireles, A., Gomes de Almeida, V., de Fátima Pereira, W., Alves de Avelar-Freitas, B. \& Eustáquio Alvim Brito-Melo, G.. 2017. Dimethyl Sulfoxide (DMSO) Decreases Cell Proliferation and TNF- $\alpha$, IFN- $\gamma$, and IL-2 Cytokines Production in Cultures of Peripheral Blood Lymphocytes. Molecules, 22(11):78-89.

Diachanty, S. \& Nurjanah, A.A., 2017. Aktivitas antioksidan berbagai jenis rumput laut cokelat dari Perairan Kepulauan Seribu. Jurnal Pengolahan Hasil Perikanan Indonesia, 20(2):305-318.

Doğan, A., Otlu, S., Çelebi, Ö., Aksu, P., Sağlam, A.G., Doğan, A.N.C.\& Mutlu, N., 2017. An investigation of antibacterial effects of steroids. Turkish Journal of Veterinary and Animal Sciences, 41(2):302-305.

Edwards, M.S. \& Connell, S.D. 2012. Competition, a Major Factor Structuring Seaweed Communities. Seaweed Biology Ecological Studies, 219(2):35-156.

Hessling, M., Feiertag, J. \& Hoenes, K. 2017. Pathogens Provoking Most Deaths Worldwide: A Review. Biosci Biotech Res Comm., 10(2):1-7.

Kaharap, A.D., Mambo, C. \& Nangoy, E. 2016. Uji Efek Antibakteri Ekstrak Batang Akar Kuning (Arcangelisia flava Merr.) Terhadap Bakteri Staphylococcus aureus dan Escherichia coli. Jurnal e-Biomedik, 4(1):13-16.

Karimil, E., Jaafar, H.Z.E., Ghasemzadeh, A. \& Ibrahim, M.H. 2013. Light Intensity Effects on Production and Antioxidant Activity of Flavonoids and Phenolic Compounds in Leaves, Stems and Roots of Three Varieties of Labisia pumila Benth. Australian Journal of Crop Science, 7(7):1016-1023.

Kitiyodom, S., Khemtong, S., Wongtavatchai, J. \& Chuanchuen, R.. 2010. Characterization of Antibiotic Resistance in Vibrio spp. Isolated from Farmed Marine Shrimps (Penaeus monodon). FEMS Microbiol Ecol., 72(2): 219-227.

Kohanski, M.A., Dwyer, D.J. \&Collins, J.J. 2010. How Antibiotics Kill Bacteria: From Targets to Networks. Nat. Rev. Microbiol., 8(6):423-435.

Kusuma, S.A.F., Agung, M.U.K. \& Meika, J. 2015. Skrining Antibakteri Produk Ekstraseluler Eksosimbion Bakteri Laut pada Makroalga Terhadap Biofilm Staphylococcus aureus ATC 25923. Jurnal Akuatika 6(2):128-139.

Largo, D.B., Fukami, K., Nishijima, T. \& Ohno, M. 1995. Laboratory-induced Development of the Ice-ice Disease of the Farmed Red Algae Kappaphycus alvarezii and Eucheuma denticulatum (Solieriaceae,Gigartinales,Rhodophyta). Journal of Applied Phycology, 7(6): 539-543.

Louie, A., VanScoy, B.D., Brown, D.L., Kulawy, R.W., Heine, H.S. \& Drusanoa, G.L. 2011. Impact of Spores on the Comparative Efficacies of Five Antibiotics for Treatment of Bacillus anthracis in An In Vitro Hollow Fiber Pharmacodynamic Model. Antimicrobial Agents and Chemotherapy, 56(3):1229-1239.

Loureiro, R., Gachon, C.M.M. \& Rebours, C.. 2015. Seaweed Cultivation: Potential and Challenges of Crop Domestication at an Unprecedented Pace. New Phytologist, 206(2):489-492.

Maftuch, I.K., Adam, A. \& Zamzami, I. 2016. Antibacterial Effect of Gracilaria verrucosa Bioactive on Fish Pathogenic Bacteria. Egyptian Journal of Aquatic Research, 42(4):405-410.

Martí, R., Uriz, M.J. \& Turon, X.. 2004. Seasonal and Spatial Variation of Species Toxicity in Mediterranean Seaweed Communities: Correlation to Biotic and Abiotic Factors. Marine Ecology Progress Series, 282(1):73-85.

Masyahoro \& Mappiratu. 2010. Respon Pertumbuhan pada Berbagai Kedalaman Bibit dan Umur Panen Rumput Laut Eucheuma cottonii di Perairan Teluk Palu. Media Litbang Sulteng, 3(2):104-111. 
Mohanta, R.K. \& Padhi, S.B. 2016. Antibacterial Activity of Some Marine Macro Algae from the Coastal Environments of Southern Odisha. IOSR Journal of Pharmacy, 6(9):14-18.

Mokoka, T.A., McGaw, L.J., Mdee, L.K., Bagla, V.P., Iwalewa, E.O. \& Eloff, J.N. 2013. Antimicrobial Activity and Cytotoxicity of Triterpenes Isolated from Leaves of Maytenus undata (Celastraceae). BMC Complementary and Alternative Medicine, 13(1):111-119.

Morita, Y., Tomida, J. \& Kawamura, Y. 2014. Responses of Pseudomonas aeruginosa to Antimicrobials. Frontiers in Microbiology, 4(1):422-430.

Oumaskour, K., Boujaber, N., Etahiri, S., \& Assobhei, O. 2013. Anti-Inflammatory and Antimicrobial Activities of Twenty-Three Marine Red Algae from the Coast of Sidi Bouzid (El JadidaMorocco). International Journal of Pharmacy and Pharmaceutical Sciences, 5(3):145-149.

Owusu-Kwarteng, J., Wuni, A., Akabanda, F., Tano-Debrah, K. \& Jespersen, L. 2017. Prevalence, Virulence Factor Genes and Antibiotic Resistance of Bacillus cereus sensu lato Isolated from Dairy Farms and Traditional Dairy Products. BMC Microbiology, 17(65): 98-105.

Pérez, M.J., Falqué, E. \& Domínguez, H. 2016. Antimicrobial Action of Compounds from Marine Seaweed. Marine Drugs., 14(3):52-56.

Riyanto, E.I., Widowati, I. \& Sabdono, A. 2013. Skrining Aktivitas Antibakteri pada Ekstrak Sargassum polycystum Terhadap Bakteri Vibrio harveyi dan Micrococcus luteus di Pulau Panjang Jepara. Journal of Marine Research, 1(1):115-121.

Rusli, A., MetusalachTahir, M.M., Salangke, \& Syamsuar. 2016. Analysis of Bioactive Compounds of Caulerpa racemosa, Sargassum sp., and Gracilaria verrucosa Using Different Solvents. Jurnal Teknologi, 78(2):15-19.

Ruwandeepika, H.A.D., Jayaweera, T.S.P., Bhowmick, P.P., Karunasagar, I., Bossier, P. \& Defoirdt, T. 2012. Pathogenesis, Virulence Factors, and Virulence Regulation of Vibrios Belonging to the Harveyi Clade. Aquaculture, 4(2):59-74.

Shukla, P., Bansode, F.W. \& Singh, R.K. 2011. Chloramphenicol Toxicity: A Review. Journal of Medicine and Medical Sciences, 2(13):1313-1316.

Siregar, A.F., Sabdono, A. \& Pringgenies, D. 2012. Potensi Antibakteri Ekstrak Rumput Laut Terhadap Bakteri Penyakit Kulit Pseudomonas aeruginosa, Staphylococcus epidermidis, dan Micrococcus luteusi. Journal of Marine Research, 1(2):152-160.

Sudheesh, P.S., Al-Ghabshi, A., Al-Mazrooei, N. \& Al-Habsi, S. 2012. Comparative Pathogenomics of Bacteria Causing Infectious Diseases in Fish. International journal of evolutionary biology 1(1):34-39.

Suryabrata, S. 2003. Metodologi Penelitian Ed. 2. Raja Grafindo Persada, Jakarta, $166 \mathrm{hlm}$.

Ventola, C.L. 2015. The Antibiotic Resistance Crisis: Part 1: Causes and Threats. PT., 40(4):277283.

Wafa, N., Sofiane, G. \& Mouhameda, K. 2016. The Antioxidant and Antimicrobial Activities of Flavonoids and Tannins Extracted from Phlomis bovei De Noé. European Journal of Experimental Biology, 6(3):55-61.

Widowati, I., Lubac, D., Puspita, M. \& Bourgougnon, N.. 2014. Antibacterial and Antioxidant Properties of the Red Alga Gracilaria verrucosa from the North Coast of Java, Semarang, Indonesia. International Journal of Latest Research in Science and Technology, 3(3):179185.

Wijaya, H., Novitasari \& Jubaidah, S.. 2018. Perbandingan Metode Ekstraksi Terhadap Rendemen Ekstrak Daun Rambai Laut (Sonneratia caseolaris L. Engl). Jurnal IImiah Manuntung, 4(1):79-83.

You, J., Xue, X., Cao, L., Lu, X., Wang, J., Zhang, L. \& Zhou, S. 2007. Inhibition of Vibrio Biofilm Formation by a Marine Actinomycete Strain A66. Applied Microbiology and Biotechnology, 76(5):1137-1144. 